\title{
Capitalism and The Transformation of Social Practices in Space: The Example of Edirne Alipaşa Bazaar and Margi Shopping Center
}
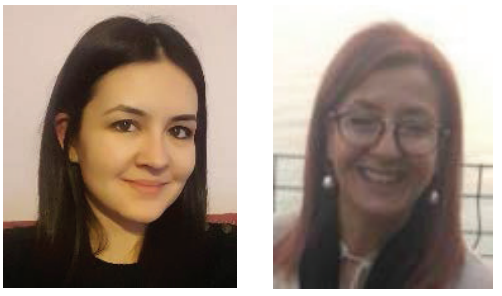

Bilge Uysal, Sennur Akansel

Trakya University, Faculty of Architecture Department of Architecture bilgeys1@gmail.com,https://orcid.org/0000-0003-1464-0407

sennurakansel@trakya.edu.tr

Received: 15.03 .2020

Accepted: 29.05 .2020

\begin{abstract}
The social change that accompanies modernization and capitalism has also brought about spatial change. In order to maintain the profitability of the capital, it has used the space as an infrastructure. For this purpose, the capital has invested in cities with the remaining amount from the labor force. The abstract qualification of the place has influenced social practices and has become a practice of increasing quantitative values. Bourdieu's habitus describes the process by which the practices of the social system are formed. The practices of the capitalist system have changed the urban space to develop the capital. Consumption society has realized its practices through image spaces in this city which is transformed with capital. In this work, the reproduction of the space and how social practices are realized in different places have been examined theoretically and by observation. Edirne's urban development has advanced in the direction of increasing profitability, and the historical city center is behind this purpose. For this reason, Alipaşa Bazaar has not been able to provide the services provided by Margi Shopping Center and has been unable to respond to everyday needs. This has affected the historical continuity of urban life and compared it with the danger of identity loss. The city center has shifted towards attraction areas like the Margi Shopping Center and has lost its historical core vitality.
\end{abstract}

Keywords: Capitalism, space, social practices, consumption

\section{Kapitalizm ve Mekânda Toplumsal Pratiklerin Dönüşümü: Edirne Alipaşa Çarşısı ve Margi Alışveriş Merkezi Örneği}

Özet: Modernleşme ve kapitalizmle birlikte gelen toplumsal değişme mekânsal değişmeyi de beraberinde getirmiştir. Sermaye kârlılı̆̆ını devam ettirmek için mekânı altyapısal olarak kullanmıştır. Bu amaçla sermaye emek gücünden arta kalan miktar ile kentlere yatırım yapmıştır. Mekânın soyut nitelik kazanması toplumsal pratikleri etkilemiş, niceliksel değerlerin artması yönünde pratikleri dönüştürmüştür. Bourdieu'nun öne sürdüğ̈̈ habituslar toplumsal sistemde pratiklerin oluşma sürecini açılamıştır. Kapitalist sistemin pratikleri sermayenin gelişmesi yönünde kent mekânını değiştirmiştir. Tüketim toplumu sermaye ile dönüşen kentte görüntü mekânları aracıliğılla pratiklerini gerçekleştirmiştir. Bu çalışmada, mekânın yeniden üretimi, toplumsal pratiklerin farklı mekânlarda nasıl gerçekleştiği kuramsal olarak ve gözlem yolu ile incelenmiştir. Edirne'nin kentsel gelişimi karlılığı arttırma yönünde ilerlemiş, tarihi kent merkezi bu amacın gerisinde kalmıştır. Bu nedenle Alipaşa Çarşısı, Margi Alışveriş Merkezi’nin sunduğu hizmetleri sağlayamamış, gündelik ihtiyaçlara cevap veremez olmuştur. Bu durum kent yaşamının tarihsel sürekliliğini etkilemiş, kenti kimlik kaybı tehlikesiyle karşılaştırmıştır. Kent merkezi Margi alışveriş merkezi gibi çekim alanlarına doğru kaymış, tarihi çekirdek canlılığını yitirmiştir.

Anahtar Kelimeler: Kapitalizm, mekân, toplumsal pratikler, tüketim 


\section{INTRODUCTION}

Capitalism, which develops first in England, Northwest Europe and Northeast America, is the rational state of the economic movement. It is the use of technically efficient production tools and scientific management methods instead of inefficient traditional methods. ${ }^{1}$ [1] The relationship between money and spatial and temporal practices that develop depending on social issues and are often the result of social struggles has been regulated in the development of capitalism. Time and space are defined by the organization of social practices that lead to commodity production. However, the dynamic power of capital accumulation and the conditions created by the social struggle made this arrangement unstable. ${ }^{2}$ [2] For this reason, spatial problems have been experienced in cities, while some places are developing faster, some places have sunk into oblivion. Capital constantly rearranges time and space in order to get rid of situations where social struggles are irregular, and transforms the production of space into commodity production.

Capitalist production made it necessary to build new markets and educate consumers through advertising and media with the scientific developments at the beginning of the 20th century. The same commodity logic and instrumental rationality in the field of production are also established in the field of consumption. Leisure, art and culture have been incorporated into the culture industry, mass produced and incorporated into a commodity culture. ${ }^{3}[3]$ With the shift of emphasis from production to consumption in capitalism, spaces have developed within the framework of the production of consumption practices. The main characteristics of these spatial organizations are the fact that consumption is controlled in a controlled manner, the credit card is valid instead of cash, most needs can be met from the same place, the items sold can be calculated, the items sold can be calculated, the same product guarantee is given everywhere, the weather and climate conditions do not change, the absence of crime and uncertainty, the presence of a hidden conveyor system. ${ }^{4}$ [4] The spatial organizations have reduced the local characteristics of the space, behavioral patterns, traditions, customs and traditions, face-to-face relations, and made communication with people who are not there important through texts. Social structure has therefore expanded in space and time. Objects, codes and symbols have had social meanings.

In order to understand the abstract effect of social structure on space, instead of the concepts of time and space that change perceptions, practices with objective values should be examined. Because although practices are geographically and historically different and constantly change due to the reproduction processes of capitalism, they cause the space to transform objectively. ${ }^{5}[2]$ In this study, the type of space production of social practices is discussed. With modernization and capitalism, the situation of changing the understanding of space and time to create a consumer society has been examined theoretically. At the same time, the realization of the practices required by the social structure in the shopping spaces is emphasized. Based on this theoretical ground, Alipaşa Bazaar and Margi Shopping Center in Edirne have been compared in terms of consumption practices and spatial organizations. The comparison method revealed that Alipaşa Bazaar is in danger of losing its historical and architectural identity values, and that the historical core of Edirne has lost its importance in terms of settlement. The infrastructural formation of spatial organizations could be evaluated within the framework of the effect of capitalist capital accumulation on urban development.

\section{SPACE AND SOCIAL PRACTICES}

Space is specified in the architectural dictionary as an emptiness that separates the human being from the environment to a certain extent and enables the activities to be continued. ${ }^{6}[5]$ However, space is not only a

\footnotetext{
${ }^{1}$ Bocock, R.,2014, p. 45

${ }^{2}$ Harvey, D., 2012 p. 269

${ }^{3}$ Featherstone, M., 2013 p.40

${ }^{4}$ Y1rtıc1, H., 2005 p.79-82

${ }^{5}$ Harvey, D., o.c., 2012 p.230

${ }^{6}$ Hasol, D., 2005 p. 313 
limited emptiness but also a social product. Lefebvre divided the formation of social space into three as perceived, designed and lived spaces. The perceived space includes the interaction of the person with his environment, the designed space includes the use of mental processes, and the living space includes the complexities in daily life and the formation of culture. ${ }^{7}[6]$ In other words, social space is formed due to the perception of the society, the spatial organizations in which practices are produced and the changes experienced during the realization of these practices in the space. In this study, the issue of creating social practices by the space in the process of human inclusion in a certain social environment and the physical transformations it undergoes in this process are emphasized.

The human body naturally reproduces space, just as a spider forms its web. While the space gains the direction of movement with the body, it leaves the abstract quality and has a concrete quality and moves from the mental to the social. The movement of the body produces spaces specific to each practice. ${ }^{8}[6]$ The original practices produced come together in the space and form the social space. The systems that regulate the movement of the body are called habituses. These systems are the tendencies that occur in the body in social life. Our practices are the product of our habitus. Habitus are original and creative because they are in the body, so the actions they produce are also unique. People with similar habitus perform similar practices and actions. ${ }^{9}[7]$ The practices that habituses produce in this way enable the perception of space by living with the movement of the body. The formation and continuity of the space take place through practices. Space is integrated with the concept of time by means of the body and is affected by the characteristics of time. Changing practices in the body over time also reproduce habitus. Habituses constitute the social structure through the practical logic they produce. In this formation process, the environment and society take shape and the sources of information used in daily life are re-formed. The renewed sources of information determine social groups, class distinctions, identity achievements and behaviors. ${ }^{10}[8]$ Social structures exist in concrete form as practices, not abstract in space. If social structures are not reproduced by practical logic, the movements of the body are limited, social sameness occurs, and the features peculiar to the place disappear. When the body is limited in space, it resists against it and tries to regain a social character by changing the existing order. The effects against social practices in space are interventions to the body.

The concept of modernization, which we use to mean the development of social life, has made life dependent on the land dependent on the cities with capitalism, which is an economic system that regulates production and consumption relations. Capital concentrated on the regions it wanted and established new economy-based geographies. The increase in capital and the change in production methods caused crisis and chaos, in which case the space was rearranged. The fact that the labor force is out of the workers' control and can be exchanged has increased the migration to the cities. Production is no longer intended for need, but for circulation under market conditions. ${ }^{11}[4]$ The fact that life dependent on the land has become dependent on the cities has concentrated the capitalist space in the cities. Social organization and coexistence have been realized by organizing practices in cities. Capital has changed and transformed the capitalist space, causing a change in practices.

The rapid production of the space together with the land has weakened the social aspect of the space. The space, whose social aspect has weakened, has been produced with Cartesian thought and has become an object separate from the subject. The space formed in this way did not have a certain direction, the space lost its harmony with the body. ${ }^{12}[6]$ Priority has been given to the practices of capitalism over the nature of

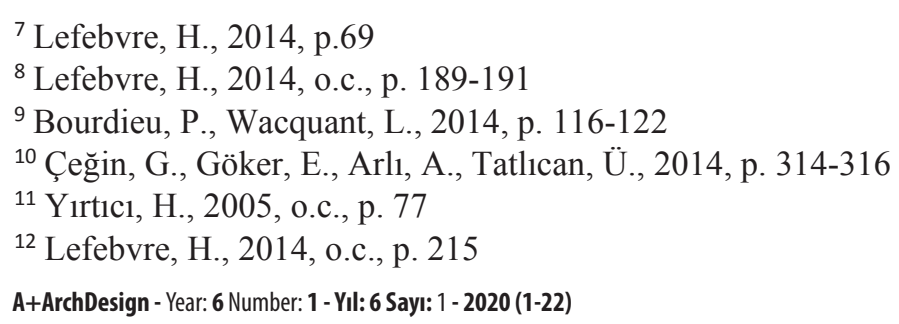


the body in space. When discriminations such as class, race and gender occurred, the body was negatively affected by this situation and reproduced itself to adapt to the situation. Practices have developed against the forces of socialization, discipline and punishment. Generalizations about practices should be made to understand the resistance to these forces ${ }^{13}$ [2] In order to make the spatial evaluation of the contemporary capitalist society, the social structuring and the social values established on it should be examined first. In order to reveal the mobility of capitalism in space, practices should be examined and their relations with space should be evaluated. In order to preserve the existence of spatial differences, capital must find its place in the global flow. In a system determined by the consumption ideology by the capitalist economy, the practices produced by the habitus reflected in the act of consumption as a circulation value should be applied to the space.

\section{CHANGE OF SPACE-TIME UNDERSTANDING}

In tribal societies and societies divided into classes, the routinization of daily life and social life consisting of regular practices are regulated by tradition. The disappearance of the ongoing influence of tradition in post-medieval Europe is the result of many different factors. However, the transformations in labor and property, which took concrete form in the formation of capitalist urbanization, caused the radical loss of the power of tradition, which is the main source of the routinization of daily life. With the development of urbanization and capitalism, the concept of community has disappeared, the concept of mass society has emerged, and this concept has become integrated with the concept of industrial society. ${ }^{14}[9]$ The forms of organization in the mass society, together with capitalism and modernization, have created new space-time conceptions. It has been re-established and organized with time and space control mechanisms. Social practices have also transformed by being affected by this process.

The disappearance of tradition occurred through three transformations. The first of these is the transformation and commodification of labor into labor force as a means of surplus value. In this way, there was a loss of control over labor time and the products of labor, and the meaning of labor was weakened. Peasant labor was a natural component of broad community practices, and workers had a close and knowledgeable relationship with nature ${ }^{15}$ [9] When labor is divided into concrete and abstract labor, these values are united in the exchange process. Here the money-commodity relationship has come to light, people in the market are defined as buyers of things. Money has become the measure of value and a means of circulation. In traditional societies relations were in the form of commodity-money-commodity, this circulation shifted with capitalism to the circulation of money-commodity-money + surplus value (profit). Labor power could be bought and sold in the market and therefore used to generate surplus value. ${ }^{16}[10]$ The quantification and commodification of time have increased the control of class processes over the production process. For these reasons, the link between labor and the products of labor has been weakened. Social practices in space have transformed from task oriented to time oriented. Changing social relations have begun to move from rural to urban areas, social relations in the city have been realized with the help of roles and different statuses have emerged.

The second important transformation is the transformation of the temporal and spatial routes of the day. Work, leisure and leisure time are cut off from social activities. Time has been created, objectified in the sense of being detached from the practices of social life. This situation increased the effect of capitalist control and created the distinction between public and private spheres, and home-work place. People's bond with where they live has been weakened. In short, space and time are arranged for actions that will serve the capitalist system. The third transformation is the commodification of urban land into created space, that is, the daily residence of the majority of the population. The created space is far from being in relation to

\footnotetext{
${ }^{13}$ Harvey, D., 2012, o.c., p. 230-239

${ }^{14}$ Giddens, A., 2000, p.164-166

${ }^{15}$ Giddens, A., 2000, o.c., p.164-166

${ }^{16}$ Harvey, D., 2015, p.124-125 
nature. Capitalism has produced the boring physical environments in which urban life is maintained with architectural functionalism. The moral bindingness of traditional practices has been replaced by habits based on economic difficulties. ${ }^{17}[9]$ The land was owned and administered by the profit-seeking class. The value of objects and soil has constantly changed according to market conditions, and their qualitative values have been pushed to the background. Attachment to objects and land has disappeared, and they can move dynamically in the market. In this way, the place can now be purchased ready-made, and its quantitative value has been affected by market conditions. The quantitative value gained by the space has caused it to be produced quickly and designed to respond to different functions in order to keep up with this change.

It has been possible to seek profit by changing the use and definition of space and time. The material exchange of commodities has required displacement and spatial movement. Every complex production system required the organization of space. Overcoming spatial barriers took time and money. Therefore, the efficiency of spatial organization and movement has become an important problem for all capitalists. Effective spatial organization has affected the socially required turnover time. ${ }^{18}[2]$ Abstract relations in cities have become concrete with the organization of space, and social patterns become objectified with space. The capitalist system has transformed the space into infrastructure to maximize its profits, eliminating differences. In this way, different geographies have been connected to each other in a similar time-space understanding and the global economic system has been formed. The social world consists of four-dimensional time-space entities that are interdependent and mutually changing in temporal-spatial terms. Marx argued that the development of capitalist relations has the effect of overcoming all spatial barriers, and therefore space is destroyed by time. Spatial organizations are essential to overcome space. ${ }^{19}$ [11] Spatial organizations can be reconstructed by the quantification of space and time. The spatial organization of capitalism has ensured domination over space and time, increased profitability and weakened the bond with place. For example, factories have forced workers to break from their own rhythms and work in accordance with the rhythm of the factory.

Modernity, which expresses the change in social life and organization forms, separated time from space by time zones, detached social activities from their localized contexts and rearranged them in developed spacetime distances. At the same time, it produced systematic knowledge of social life, and this situation made social life a part of reproduction by moving away from the invariability of tradition..$^{20}$ [12] Modernity has been associated with the four great revolutions. The first is that in daily life, the laws of nature apply instead of the rules of God. The laws are based on a cause effect relationship. Second, with the political revolution, the source of power has been the people, not god. Mind came to the fore in the administration and democracy was adopted. Third, with the cultural revolution, social relations and thought system became secular. Fourth, with the industrial revolution, vehicles have become technological and nature has been taken under control. In this way, the production of the material world has increased, people have acquired the objects ready. ${ }^{21}[4] \mathrm{W}$ ith these revolutions, freedom and social welfare have increased, social practices have constantly renewed, new situations and new knowledge have emerged. With these changes, cities have also changed, new residential areas and new centers have emerged. Space and time have been reorganized in cities. The freedom and progress understanding of modernity has been reached with the practices of capitalism. Capitalism has invested in places by transforming surplus value into capital, capital has grown continuously, social relations have created new spatial arrangements.

The concentration of capital, the spatial concentration of production tools, management units and workforce have led to the concentration of consumption tools they need. At the same time, the increasing dependency

\footnotetext{
${ }^{17}$ Giddens, A., 2000, o.c., p.167-198

${ }^{18}$ Harvey, D., 2012, o.c., p.258-262

${ }^{19}$ Urry, J., 2015, p.109

${ }^{20}$ Giddens, A., 2014, p.57

${ }^{21}$ Yirtic1, H., 2005, o.c., p. 24-25 
between production and management units has prevented the being up and running of the economic process. These processes have led to the formation of large urban structures. The role of the labor force in the production has expanded with technological developments. The dependency between technical and economic units required the workforce to work more programmatically. Therefore, the skills of the workforce had to be increased. The increasing importance of the labor force has equally increased the role of common consumption tools and public resources and services. Services such as housing, school, kindergarten, nursing home, health, culture, transportation have become obligatory in terms of the needs of the urban structure and production process. ${ }^{22}$ [13] Space has become a part of social organization, not a natural state and an ontological area of existence as in the classical understanding. For this reason, many different disciplines come together while creating space within the capitalist system. Mass culture should also be well understood, as production takes place in mass. Material life and human lives should be examined in order to watch the transformation of the space.

Events and processes have become increasingly interdependent in the organization of capitalist labor and time. Everything depends on developments elsewhere. Ephemerality is important. There is shortevity in products, fashions, ideas, values, technologies and the like. Immediate and disposal are emphasized. Not only in material things, but also in values, lifestyles, relationships, and attachment to place, all were easily discarded. Short-term, indicators and images are important. A worldwide industry has produced and marketed images not only for products but also for people, governments and the like. ${ }^{23}[11]$ Social change took place rapidly in space and time, by means of impermanence, instantness, and short-term. The abstract quality of space and time has created new conceptions of time and space, and social relations have begun to take place in abstract space systems. With communication and information technologies, spatial places have turned into flows. Production and consumption are no longer dependent on a specific location, global markets have emerged.

Globalization and localization trends combined with image spaces. The accumulation was organized in different ways, and new commercial integration and fragmentation occurred. Image spaces have increased the dominance of images, the image industry has influenced and colonized the psychic world. In this world where images dominate, people have had difficulties in positioning themselves, and people's creation of culture has been taken under control. ${ }^{24}[14]$ The texts have defined new spatial uses by ensuring the control in the space. Face-to-face interaction has decreased in modern spaces with texts. The texts showed the existence of people who were not there and formed an important source of information. Social systems have expanded by interacting with people who are not there through texts. The expansion of social systems and the realization of social change required movement in time and space. Western industrial capitalism has spread around the world using space. Spatial organizations where this spread occurs the fastest, the relationship of the space with the place is weakened, the impermanence and short-life are emphasized, the images take place and the consumption becomes the first-degree important spatial organizations have been airports, ports, highway systems and shopping centers.

\section{THE FORMATION OF SOCIAL PRACTICES IN SHOPPING SPACES AND THE CONSUMPTION SOCIETY}

In general, shopping is the purchase of some product for a certain price. However, the phenomenon of shopping is a form of behavior in which social communication and interaction are effective beyond the exchange of products for money. For this reason, shopping spaces in history have added vitality to city life..$^{25}[15]$ Agoras in ancient cities and squares in medieval cities constituted the most important shopping spaces of the cities. In these places, shopping activity has included urban functions such as gathering for

\footnotetext{
${ }^{22}$ Castells, M., 2014, p. 256-258

${ }^{23}$ Urry, J. 2015, p.263- 264

${ }^{24}$ Morley, D., Robins, K., 2011, p. 52-67

${ }^{25}$ Vural, T., 2005, p.115 
various purposes and social communication with other citizens. The urban space and the shopping area are intertwined. The shopping space was at the core of the city and formed a multifunctional public space. ${ }^{26}$ [16]

Small craft production in pre-industrial societies was one of the society's main sources of income. The products used by the low-income groups were produced in the small shops and houses of the craftsmen in the market area and sold at low prices. The products used by the low-income groups were produced in the small shops and houses of the craftsmen in the market area and sold at low prices. The goods of nobles and courtiers were produced by masters and sold to privileged people at high prices. While low-priced products are available in almost every city, marketing of products that require specialization has been sold in a small number of cities. For example, special glass production in Venice, production of silk fabrics in Bursa. These products were sold in trade centers on historical trade routes. Ottoman cities generally developed around the market area. The bazaar area consists of one or more streets lined with inns, covered bazaars and workshops. Inns have been used by craftsmen, merchants and travelers for accommodation and trade. Bedestens, on the other hand, are the centers of the settled and traveling merchants. ${ }^{27}[15]$

Between the 16th and 19th centuries, the trade center was transformed due to the changes in social and economic relations within the Ottoman urban system. Craft activities have shifted to trade events. The area covered by the bazaar has expanded. Building density and activities in buildings have increased. The functions realized in building types are concentrated. While the craft preserved its old structure, trade grew. [17] As the 1800s approached, with the industrialization developing in Europe, intense migration to cities started. With this migration, a large amount of food needs arose, so small market areas were insufficient. From the beginning of the 1700 s, products such as fruits, vegetables and fish began to be sold in locations far from the city centers, with large closed market areas. These market areas that emerged in the 18th century were the first examples of large shopping centers. After the industrial revolution, the historical trade routes declined in importance and accommodation activity in trade centers gave way to sales activity. In this period, as a result of rapid urbanization, consumer needs and consumer products diversified and these products started to be sold in newly formed passages. Beyond being a place of trade, the arcades have become places where modern urban life has flourished. ${ }^{28}[15]$

Until the 18th century, city life, which was generally under the rule of a dominant political authority, has undergone various changes with the effects of capitalism. These effects have occurred as a result of industrialization and globalization processes. The newly formed city is an industrial city and a commercial center. Administrative and religious functions have lost their importance. Urban space is wider than the pre-industrial city. The roads have widened, the structures have risen. Privatization in urban land use has increased. There has been a distinction between residence and workplace. Urban recreation areas have increased..$^{29}[18]$ With the increase of technology and industrialization in the 19th century, Taylorism, the production system based on the division of labor over the machine, gave way to the Fordist mode of production. Fordism has preserved old technologies in the field of labor process, and increases in productivity have been achieved by shifting work to the unmoving worker. Using the assembly line, workers do one thing in one move. Uneducated labor force could be used. Standard product output was obtained, and a large number of products were produced from the same product and sales were made at low prices..$^{30}[4]$

With the systematization of production and the introduction of machinery, products began to be produced

\footnotetext{
${ }^{26}$ Birol, G., 2005, p.422

${ }^{27}$ Vural, T., 2005, o.c., p. 120-123

${ }^{28}$ Vural, T., 2005, o.c., p. 124-126

${ }^{29}$ Gemici, E., 2007 p.8-9

${ }^{30}$ Yirtıc1, H., 2005, o.c., p.42 
faster and in greater quantities than those produced by craftsmanship in pre-industrial times. An understanding similar to the systematization of production in factories has to be applied to the marketing of products in shopping areas. It is no longer meaningful to sell identical products at different prices in different stores and to bargain for them. Therefore, there was a need for shopping spaces and large stores where new market strategies were developed and implemented. Large stores first appeared in 1852. In these venues, the profit rate is low, the sales volume is wide, the prices of the goods are fixed and clearly stated. In these venues, the profit rate is low, the sales volume is wide, the prices of the goods are fixed and clearly stated. Everyone can enter these stores and look around. Products started to be displayed with goods that support each other or stand out, and consumers were interested not only in the products they needed but also in different types of products. ${ }^{31}[15]$

In the period after the Second World War, restructuring occurred in Europe, along with the physical structure, the cultural structure also changed. In the pre-industrial period, cities had housing, small craft and trade in their centers, but today they have been divided into different activity areas as a result of industrialization, the development of motorized transportation vehicles and economic developments. Therefore, instead of concentrating around a single center, cities have turned into units where different subcenters come together. ${ }^{32}$ [19] New shopping areas called supermarkets have emerged to meet the needs of residents outside the city. Baudrillard likened hypermarkets to an assembly plant. The difference of hypermarkets from assembly plants is that employees wander from one part of the space to another rather than walking around in successive stages. Consumers come here whenever they want, choose and buy. But this hyperreality has a hidden mounting band behind it. ${ }^{33}[20]$

The existence of the Fordist mode of production depends on the existence of standard consumption patterns on the one hand, and the existence of broad and stable markets on the other. Markets should be large enough to allow for the sale of standard goods and be stable enough for a large investment to redeem. Consumption amount is important in a production style dependent on these conditions. Production costs must be minimized constantly. With the end of the 60 s, the standard consumption patterns of the society began to change, and consumer demands have diversified and gained a constant change depending on the increasing level of welfare. "Flexible accumulation", which is defined as the dominant production practice today, is structured within the newly developing consumption relations. Diversity, the ability to respond instantly to changing requests, even constantly creating new needs, desires, and providing a production organization suitable for the continuous change and diversification brought with it have become structural relations that form flexible accumulation. ${ }^{34}[4]$ The increase in consumption relations and at the same time the decrease in the pedestrian density in the contemporary city space and the fact that these places become a central business area consisting of streets and multi-storey buildings completely devoted to vehicle traffic have created an environment for the recreation of this space within the building. The most important representative of this situation is the modern shopping center. For the first time in America, Victor Gruen stated that social requirements, as well as physical requirements, will be met in an urban environment that is safe, protected, air-conditioned, isolated from vehicle traffic and designed the Northland Shopping Center. ${ }^{35}[16]$

The shopping center phenomenon in the United States can be explained in the context of the fundamental changes that occur in the organization of the social sphere that affects urban life. These are summed up by the concept of reducing density, that is, spreading the population and economic activities across the metropolitan area. This process requires the restructuring of the central city and the surrounding

\footnotetext{
${ }^{31}$ Vural, T., 2005, o.c., p. 127-129

${ }^{32}$ Vural, T., 2009, p.148

${ }^{33}$ Baudrillard, J., 1998, p.98

${ }^{34}$ Yirtıc1, H., 2005, o.c., p.100-101

${ }^{35}$ Birol, G., 2005, o.c., p.423 
metropolitan region in accordance with the new logic of global capitalism and the abandonment of industrialization in developed economies. The result of the changes in the social sphere since the 1970s has been a new settlement model -multi-centered metropolitan area- in terms of quality. The economic structure has been articulated with units that gain independence from a center and the need for coexistence, and are separated from the centralization that is becoming more and more specialized every day. Thus, chain stores, factories, bank offices, McDonalds type fast food restaurants, mass meeting places are all built on the larger areas of the growing metropolitan area. ${ }^{36}[21]$ Modern stores and shopping centers have increased repeatedly in many different regions. The sameness that took place in this way was reflected in the social life in the city. Capitalism has organized the practices that take place in the city in line with its own needs, the practices of the system have dominated the social life.

The fundamental problem of contemporary capitalism is no longer the contradiction between the maximization of profit and the rationalization of production, but between the necessity of placing and selling products produced with potentially unlimited productivity (at the level of technology). At this stage, it has become vital for the system to control not only the production device, but also the consumption demand, not only the prices, but also what will be demanded at this price. It is a natural feature of the system that the individual's behaviors adapt to the market and, in general, social attitudes adapt to the needs of the producer and the goals of the techno-structure. Contrary to the previous one, it is the producer firm that controls the market movements, manages and models the needs with social behaviors, that is, the production order. ${ }^{37}[22]$ Therefore, consumption has developed depending on the production order. For the continuity of the production order, consumption practices are designed in the space and implemented with guidance. The guidance provided by the texts minimizes the seller-customer relationship, suggesting that it provides freedom to the person. This freedom is realized in the form of an illusion, as practices are predetermined. However, consumption is also a system that ensures the regulation of indicators and the integration of the group. Therefore, consumption is both a moral and a communication system, a structure of exchange. Pleasure defines autonomous and finite consumption. However, consumption is never that. When the pleasure is consumed, it is never consumed alone, it is entered into a system of widespread exchange and coded production values in which all consumers are mutually included in spite of themselves. In this sense, consumption is a signification order like language or kinship system in primitive societies ${ }^{38}$ [22] Common characteristics of airports, ports, highway systems and shopping centers where consumption action takes place and is connected to the production system are efficiency, calculability, predictability and control. ${ }^{39}$ [23]

1. Efficiency is the selection of the optimum method for a purpose. It would be inefficient for people to discover the best tools for their purposes on their own every time. Internal rules and regulations also ensure high efficiency. Large stores with all kinds of products are more efficient than shopping at a number of specialty stores spread across the city or suburbs. The use of credit cards has increased efficiency.

2. Computability emphasizes what can be calculated, counted, quantified. Quantity has begun to replace quality. Computability and processing speed will be higher. The quantified products and processes become more predictable because the same material is required everywhere.

3. Predictability allows people to know in advance what they will encounter in a rationalized society. Those wandering in the mall are away from criminal acts and bad weather conditions that can disturb them in the city streets. In the mall, children can play safely in the playground.

4. Increased control and unmanned technologies have begun to replace humans. Inspection is carried out not only with machinery and tools, but also with materials, skills, knowledge, rules and regulations, processes and techniques. The robot, computer and assembly line inspect the visible,

\footnotetext{
${ }^{36}$ Gottdiener, M., 2005, p.121-124

${ }^{37}$ Baudrillard, J., 2013, p.75

${ }^{38}$ Baudrillard, J., 2013, o.c., p.84-87

${ }^{39}$ Ritzer, G., 2014 p. 73-191 
while bureaucratic rules, handbooks explaining the procedures and techniques adopted, also inspect the less obvious. This way, people no longer cause uncertainty or unpredictability, because they are no longer directly involved in the process.

All these criteria that constitute the space have destroyed the memory for the use of the space by pushing the local features, behavioral patterns, traditions, customs that are effective in the formation of the space. The determination of space by social consensus has disappeared. These criteria produced for the realization of the capitalist system have had a say in the use of space. The design methods of consumption spaces could not be explained with traditional space concepts. These concepts transformed into new concepts with the process that started with the transformation of the space by capital, and new spatial arrangements occurred. These concepts explained that the relationship of space with the place disappeared, the quantified space repeats in every geography, the size of the space increased and became independent of its qualities, the relationship between function and form was reduced to the shell and the bond between inside and outside was cut, the space reduced to the infrastructure is detachable and adaptable to changing market conditions, and the location of the product groups in the space is arranged according to marketing strategies within the services. At the same time, he stated that the users of the space became consumers, the experience and memory in the space were destroyed, the use of the space was given by texts and showcases instead of them, the use of space was given to consumers by means of the hidden assembly line and labor power was saved, the capital increased its profits by making arrangements of time and place with demonstrations, that every enterprise that takes place in the space has a quantitative value and that the hyperreal environments created create illusions of abundance and need. ${ }^{40}[4]$

The aforementioned common features of consumption places have created social practices and these practices have taken place in spaces. Practices have made shopping faster, easier, more efficient and safer. Practices and factors generating practices are specified in the table below. (Table 1) Consumption practices are realized by the organization of the space of the consumption society, which is formed by the rationalization of consumption tools after the means of production. Practices in the spaces are conveyed through face-to-face interaction or written communication with those who are not there. In this way, the ideology of the social structure is formed through spaces. The desire for holistic welfare is provided with small satisfaction, and the complexities and conflicts that may occur are prevented. In this way, the society is taken under control more easily, and the practices organized direct the society.

${ }^{40}$ Yirtic1, H., 2005, o.c, p. 111-151 
Table 1. Efficiency, calculability, predictability and control principles lead to social practices

\begin{tabular}{|c|c|c|c|}
\hline Principles & Systems & $\begin{array}{l}\text { Changing } \\
\text { Concepts }\end{array}$ & Social Practices \\
\hline \multirow[t]{14}{*}{ Efficiency } & \multirow{3}{*}{$\begin{array}{l}\text { Connecting shopping } \\
\text { centers to the highway } \\
\text { system }\end{array}$} & Context/Field & Accessibility and parking \\
\hline & & Context/Field & Having an urban function \\
\hline & & Scale/Size & $\begin{array}{l}\text { Being able to define the space } \\
\text { from outside }\end{array}$ \\
\hline & $\begin{array}{l}\text { Credit card valid } \\
\text { instead of cash }\end{array}$ & Quality/Quantity & Safe shopping \\
\hline & \multirow[t]{10}{*}{$\begin{array}{l}\text { Meeting all needs } \\
\text { from the same place }\end{array}$} & Incident/Demonstration & $\begin{array}{l}\text { Responding to consumption } \\
\text { demands }\end{array}$ \\
\hline & & Incident/Demonstration & $\begin{array}{l}\text { Being able to appeal to the } \\
\text { customer }\end{array}$ \\
\hline & & Experience/Text & $\begin{array}{l}\text { To be able to freely act of } \\
\text { consumption }\end{array}$ \\
\hline & & Space/Infrastructure & Ability to increase consumption \\
\hline & & Function/Service & $\begin{array}{l}\text { To be able to describe the } \\
\text { products separately }\end{array}$ \\
\hline & & Scale/Size & $\begin{array}{l}\text { Ability to move around in the } \\
\text { store }\end{array}$ \\
\hline & & Scale/Size & $\begin{array}{l}\text { Ability to move horizontally and } \\
\text { vertically }\end{array}$ \\
\hline & & Scale/Size & $\begin{array}{l}\text { Providing an attractive and } \\
\text { spectacular space }\end{array}$ \\
\hline & & Function/Service & Socialization \\
\hline & & Function/Service & $\begin{array}{l}\text { Ability to engage in activities } \\
\text { other than shopping }\end{array}$ \\
\hline Computability & $\begin{array}{l}\text { Quantification of } \\
\text { objects }\end{array}$ & Quality/Quantity & Safe shopping \\
\hline \multirow[t]{3}{*}{ Predictability } & $\begin{array}{l}\text { Finding the same } \\
\text { quality everywhere }\end{array}$ & Quality/Quantity & Safe shopping \\
\hline & $\begin{array}{ll}\begin{array}{l}\text { Control of } \\
\text { and }\end{array} & \begin{array}{l}\text { weather } \\
\text { climatic }\end{array} \\
\text { conditions } & \\
\end{array}$ & Form/Shell & $\begin{array}{l}\text { Shopping in all seasonal } \\
\text { conditions }\end{array}$ \\
\hline & $\begin{array}{l}\text { No crime and } \\
\text { uncertainty }\end{array}$ & Incident/Demonstration & Safe shopping \\
\hline \multirow[t]{3}{*}{ Control } & $\begin{array}{l}\text { Hidden } \\
\text { system }\end{array}$ & Usage/Assembly Line & \multirow[t]{3}{*}{ Safe shopping } \\
\hline & $\begin{array}{l}\text { Eliminating the error } \\
\text { with the computer }\end{array}$ & Incident/Demonstration & \\
\hline & $\begin{array}{l}\text { Controlling the flow } \\
\text { of goods }\end{array}$ & Quality/Quantity & \\
\hline
\end{tabular}

\section{TRANSFORMATION OF SHOPPING SPACES IN EDIRNE}

Edirne was founded as a city with strong defense, on the banks of the Tunca River during the Roman Empire, at the junction of the roads leading into the Balkan. Due to its location, its trade was developed and it was the capital of the Ottoman Empire. Land and river transportation has made Edirne a trading center. Its commercial, cultural, artistic and architectural features come to the fore. Industry in Edirne started to 
develop especially during the II. Murat period. Since it is on the Silk Road, it has become a large business center. This situation led to the construction of large caravansaries and inns. ${ }^{41}[24]$

Trade relations took place with Romania and Hungary in the 16th and 17th centuries. Edirne has become a city that mediated between the Mediterranean and the Danube. Among the goods that came to Edirne in the 18th century, the most important ones were the woolen fabric types known as London. Edirne sold wool, buffalo leather, silk and wax in return for this foreign purchase. After the proclamation of the Republic, trade in Edirne continued mainly in agriculture. Sunflower, sugar beet, wheat, rice, milk and dairy products are processed in factories and alms in the region. Industrial products such as textiles and apparel have been produced after the 1970s. Since 2000, with the Pazarkule border gate being kept open, there have been important developments in shuttle trade, excursion tourists have started to shop. ${ }^{42}[25]$

Although agricultural activities are predominant in Edirne, it has been the stopping point of trade between European countries and Anatolia due to its geographical location. In addition to the local people of Edirne, those coming from Balkan countries and those who want to go to Europe from the vicinity of Istanbul used the shopping areas. This situation has contributed to the development of tourism in Edirne, which has historical characteristics. Within the scope of the study, the variation of the shopping action according to the space was examined by comparing Alipaşa Bazaar and Margi Shopping Center. This analysis revealed the effects of urban development on social practices.

In the study, the first example given to shopping spaces in Edirne is Alipaşa Bazaar. Alipaşa Bazaar was built in 1561 by Hersekli Alipaşa by Mimar Sinan in order to gather the merchants who sell precious goods under a single roof. There are 130 shops and 6 gates in the bazaar. The length of the bazaar is 300 meters. Shops are lined around a large closed street from the Balıkpazarı gate to the İgneciler gate. In the Ottoman period, needle makers, coppersmiths, blacksmiths, cotton dealers, fishermen, painters, halvacists bazaar was located here..$^{43}[24]$ The Bazaar is located in the city center of Edirne, at the intersection of Talatpaşa Street and Saraçlar Street (Figure 1). The urban texture has developed in a way to highlight the covered bazaars, mosques and bazaar. The bazaar has defined the transition axis at the core of the city. The shopping activity that takes place here is in a dialectical relationship with the urban space. The bazaar is compatible with the human scale and other buildings on the street. The gates of the bazaar connect with the streets where trade is located, and the urban life in the streets flows seamlessly in the bazaar (Figure 2).
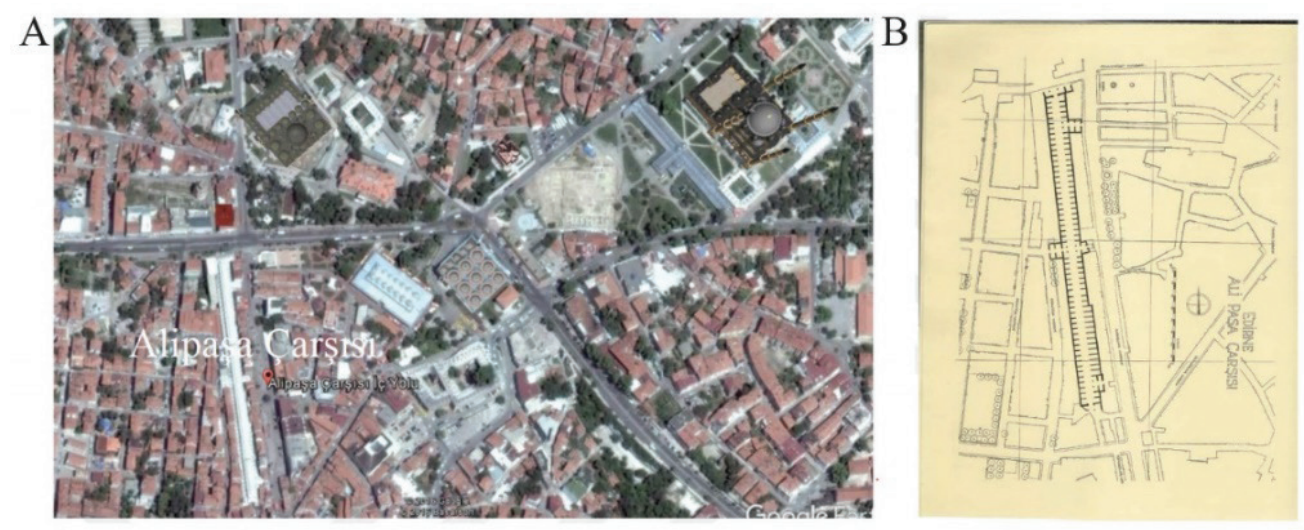

Figure 1. Alipaşa Bazaar Location; (A) Alipaşa Bazaar Aerial Photograph [26]; (B) Alipaşa Bazaar $\operatorname{Plan}^{44}[27]$

\footnotetext{
${ }^{41}$ Edirne Ticaret ve Sanayi Odas1 Rehberi, 1985, p. 36-38

${ }^{42}$ Sönmez, Ö. A., 2011, p. 63-64

${ }^{43}$ Edirne Ticaret ve Sanayi Odası Rehberi, 1985, p. 47-50

${ }^{44}$ Özdeş, G., 1988, p.24-25

12
} 

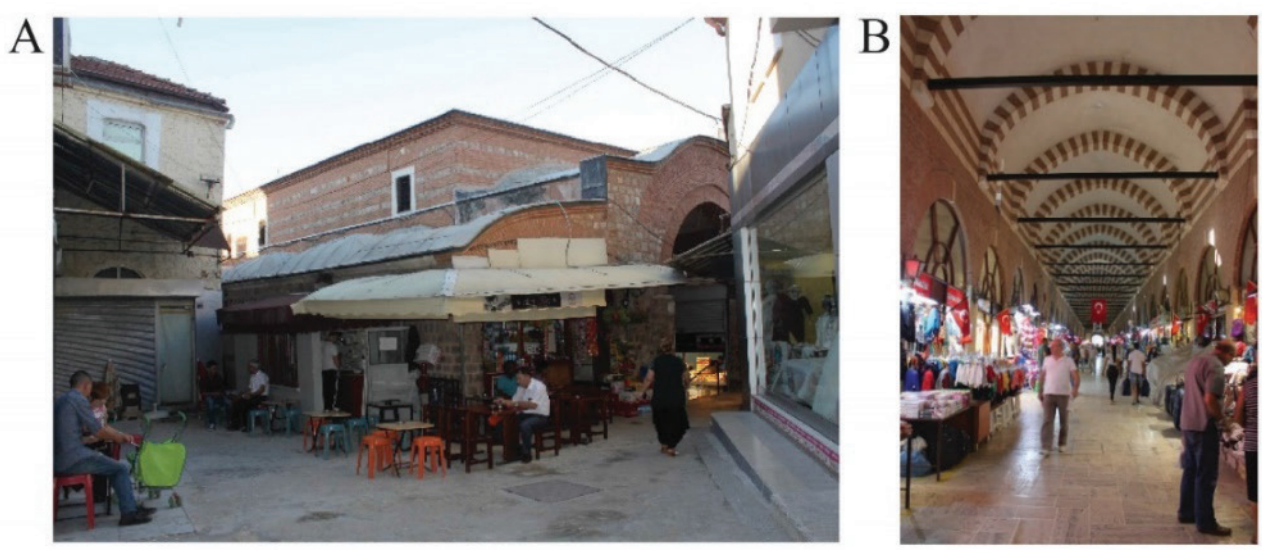

Figure 2. Alipaşa Bazaar Views; (A) Alipaşa Bazaar Gate [28] (B) Alipaşa Bazaar Interior [28]

Another example of the study is the Margi Shopping Center. This place is located in the newly developing city center of Edirne, between Talatpaşa Street, which is the Istanbul D100 highway, and Alamut Street (Figure 3). It was established on a total area of $30.000 \mathrm{~m} 2$. This region is located in Edirne's development axis in the direction of Istanbul. In order to have commercial potential, the new dense urban axis, dense residential area, industrial zone, university district were chosen as the location for Margi shopping center. Margi defined closed and open spaces according to its surroundings, and created his own square, streets and social spaces (Figure 4). Therefore, it has created a tension with the city center. The center it created has an artificial character that was later edited (Figure 5). The square, which will give the impression of an open-air bazaar or a district market, has been planned with an understanding reminiscent of the dynamic structure of the city center with cafes and restaurants with open seating areas.
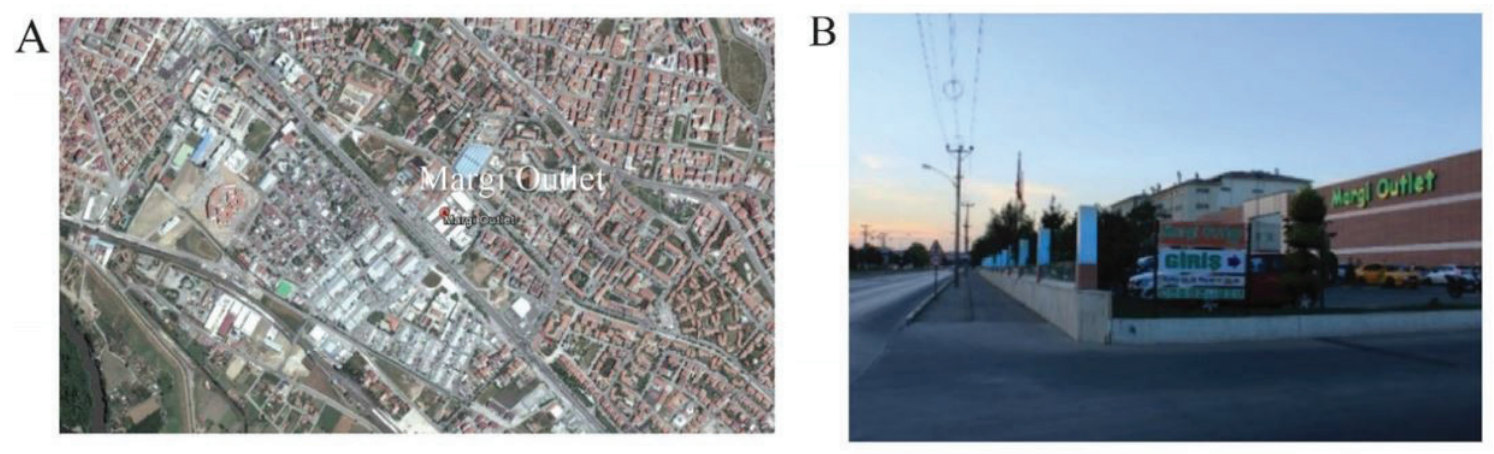

Figure 3. Margi Shopping Mall Location; (A) Margi Shopping Mall Aerial Photo [26] (B) Margi Shopping Mall Exterior View [28] 


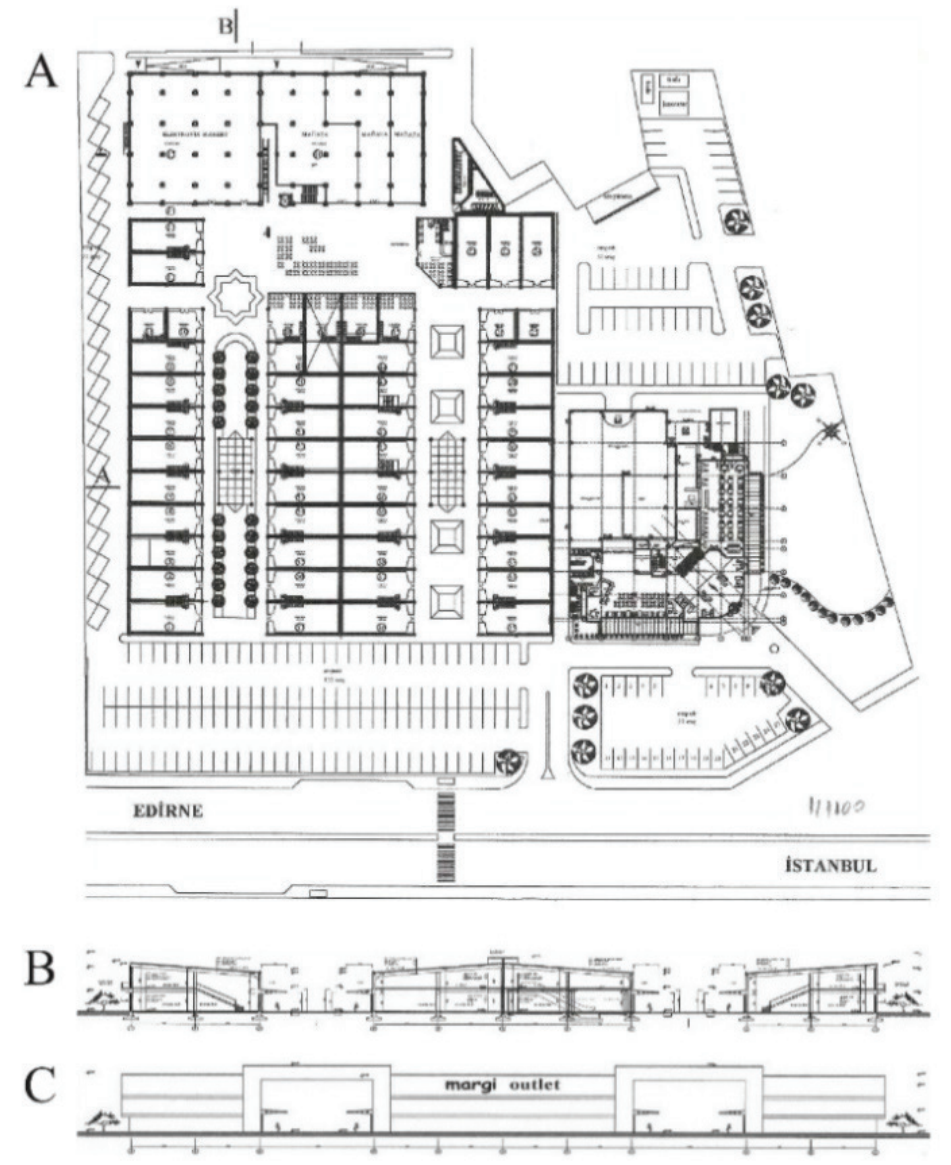

Figure 4. Margi Shopping Mall Drawings [29]; (A) Margi Shopping Mall plan (B) Margi Shopping Mall section (C) Margi Shopping Mall view

A

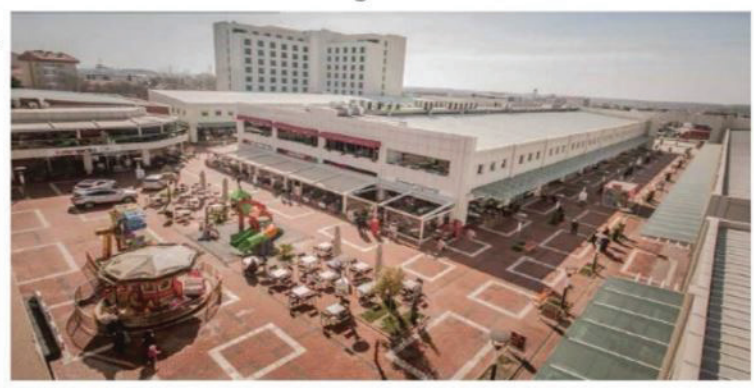

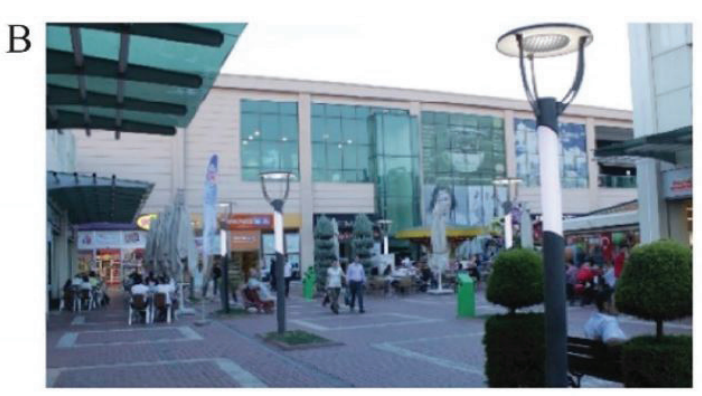

Figure 5. Margi Shopping Mall Buildings; (A) Margi Shopping Mall perspective [30] (B) Margi Shopping Mall perspective [28]

\section{COMPARISON OF ALIPASA BAZAAR AND MARGI SHOPPING CENTER IN TERMS OF SOCIAL PRACTICES}

The urban development of Edirne has been examined from a socio-spatial perspective by comparing the practices realized in the spaces. The relationship between city, space and society has been evaluated through shopping practices. The feature of being a city center formed by spaces has been revealed by comparing the practices. The main social practices that affect consumption are listed below. 
Accessibility and parking: Context integrates space with local features. However, Margi, which is connected to the highways that help the global flow of capital between geographies, has little context with the city, and its accessibility is high by means of highways that allow spatial relations. Margi is positioned in an environment based on the repetition and mechanical articulation of casual relationships. It is located in the area with high purchasing power consumer groups, depending on whether the profitability expectation will be met. Access to this area by automobile has reduced the acquaintance of transportation and the possibility of establishing a mental map. It has become a place to go, not a place to stop. Alipaşa Bazaar, on the other hand, is located within the context of the city in the historical core, in an environment connected to the pedestrian roads that create the possibility of getting acquainted with transportation and establishing a mental map. It is a place mostly frequented in the city flow. However, the dense urban texture has reduced the availability of cars and parking. For this reason, consumers cannot spend much time here.

Having an urban function: Margi has taken its place in the city based on the spatial relations determined by the capital. In other words, it is related to the position of the city in the global area rather than the local context of the city. At the same time, since its scale is large and its spatial organization is introverted, it excludes the city and establishes a world within itself. Alipaşa Bazaar, on the other hand, opens to the streets of the city and participates in the daily life of the city. According to Margi, it is more integrated with the city and has the feature of being a part of the city.

Being able to define the space from outside: Margi is bigger than human scale. It has high ceilings. For this reason, it is easy to define its buildings from outside. Because of its large scale, it is detached from external relations. It has turned into a place that works with its own internal rules without establishing a relationship with the outside. There is no sense of place in this special time and place. Alipaşa Bazaar has taken place within the urban texture and has almost disappeared in this texture. It is difficult to define space from outside. It attracts less attention of customers than Margi.

Safe shopping: Due to the private security systems at Margi, there are no coincidental incidents that have not been set up beforehand. Capital has excluded unwanted events from the space. Instead of events, demonstrations take place in Margi. The show is fictionalized, its purpose, process and result is a specific time-space arrangement. The capital organizes the shows according to its own interests, special days are organized in this space for show purposes and traditional consumption items are sold. These shows can be experienced in all seasonal conditions in Margi. With the transformation of the concept of quality into the concept of quantity, the establishment of the hidden conveyor system and the destruction of the error by computer prevent the occurrence of undesirable situations. The quantization of objects ensures the same quality everywhere and increases the confidence in the place. In Alipaşa, time and space are felt in the daily flow, and negotiation dialogues are experienced between the customer and the seller. However, this natural flow and the absence of a private security system can make customers feel insecure. The fact that the flow of goods is not controlled by computerized systems, and the failure to always find the same quality in products increases the insecurity in the space.

Responding to consumption demands: The activities that make up the network of relationships in Margi have turned into demonstrations. The show is a pre-fictionalized time-space arrangement, with a clear process and result. Here, the capital presents its time-space arrangements in accordance with its own interests as a demonstration to the consumer. For example, during the Ramadan Feast, entertainment is organized in the courtyard of the center and special products are sold for these special days. The purpose of this show is to respond to consumption demand. The concept of incident is excluded in Margi. Coincidental, events that occur in uncertainty that was not previously constructed do not occur in Margi. Each organization is under control and directed towards the purpose of the capital. According to changing consumption demands, architectural elements are also renewed and attraction power is provided to the center. In the Alipaşa Bazaar, activities corresponding to different consumption demands are not organized. 
In Alipaşa, nature's time and space are felt, and daily events, including bargaining dialogues, take place in the bazaar. The architectural elements in the bazaar do not change according to the demands.

Being able to appeal to the customer: The forms used in the space arrangements in Margi do not reflect the function, the urban space and social memory are arranged according to the system of codes participating in the system of indicators. The aim here is to attract the customer's attention and direct them to consumption. Because there is a competitive environment here and the stores have to be interesting. At the same time, the abundance of product range and abundance of products give the impression that it meets all kinds of needs of the customer. In Alipaşa, there is no competitive environment, there is no abundance and variety of products that can meet the needs of customers. Spatial arrangements in Alipaşa are not constantly re-made according to the indicators in order to attract attention.

To be able to freely act of consumption: Spatial relations in Margi are established with distant effects. All kinds of experience and memory of the place have been destroyed. The relationship with space is realized through texts. The texts are the user manual of the space. Packaging and shop windows provide information on discounts, installment opportunities, and the quality of the products. This information on consumption objects enables the consumer to turn to him more freely. At the same time, the expression of unlimited spaces describes the products separately and contributes to free consumption. Dining areas, entertainment areas for children, resting places offer different service opportunities to the customer and enable activities other than shopping to expand the concept of consumption. In Alipaşa, on the other hand, only shopping activities take place, services for different activities are not available, packages and showcases providing information for consumption objects cannot function adequately.

\begin{abstract}
Ability to increase consumption: Spatial arrangements have been made to be profitable in Margi, and services have been provided on the basis of infrastructural relations. Margi's introverted structure was established due to commercial concerns, and the customer was aimed to stay in the center for a longer time. The selected plan scheme is the architectural design based on the shop activity distribution, commercial concern and consumption increase, using the findings of user classes. You pass through the stores until you reach the square from the parking lot, then gather in the square and spend a long time in this center. Lighting elements, seating elements and colored panels have been used to increase the consumption factor in the transition between the stores. All these have been done in order to create a new world for the consumer society. Alipaşa Bazaar, on the other hand, was not designed with commercial concerns. The aim here is to make it easier for people to shop. A transition axis was formed by lining up the shops side by side. This transitional space within the urban fabric has also undertaken a different function than consumption.
\end{abstract}

To be able to describe the products separately: The space reduced by the capital to the infrastructure turns into a service area where relations are rearranged and temporal rhythm is created. Service is the quantitative state of the concept of function. Infrastructural relations accelerate the flow of capital by providing services. In Margi, product groups are determined according to the marketing strategy and rearranged according to changing market conditions. The boundaries of the stores are not felt due to the glass facades and the ceiling is higher than human perception. Everything can be described in this limitless space. Products are exhibited in stores according to the order of indicators, detached from their context. Alipaşa is lower than the ground level and the entrance to the bazaar can be felt by the stairs. The ceilings of the shops are lower than Margi's and the shop sizes are smaller. Its products cannot be exhibited separately in a certain order therefore it cannot attract the attention of the customer sufficiently. The products are stacked on the counters in front of the stores, the unity of the products does not make a certain meaning.

Ability to move around in the store: The fact that Margi is large for human scale has made the outside insignificant. The interior appears to be in the foreground and unlimited. You can easily navigate between the products in the stores. The size of the space causes the parts to become independent and the possibility 
of movement between these independent parts emerges. The center creates its own inner rhythm instead of the rhythm of the outside, and is detached from seasonal changes and temporal transformations. Alipaşa is closer to the human scale. The shops are small in size, so the opportunity to display products is also more limited. The products are exhibited on the counters in front of the stores and inside the small shops, but the opportunity to move between them is not sufficient.

\begin{abstract}
Ability to move horizontally and vertically: Margi is large for human scale and has two floors. In addition to the horizontal circulation between the masses, there is also the possibility of vertical circulation between floors. The square of the center can be perceived from every floor. Size and introverted planning have created a publicity that is independent from outside. This closed publicity is experienced from different visual angles with different movement options. Alipaşa Bazaar is a single-storey building. The ceiling height of the shops is less than Margi's. There is no vertical circulation possibility. The public space created is not introverted as it opens to the streets of the city. This fluid space can only be moved at ground level.
\end{abstract}

Providing an attractive and spectacular space: The spatial size required for the provision of services in Margi has enabled it to create an attractive and spectacular place. Reflective surfaces in the interior reduce the boundaries of the space, and lighting techniques reduce the perception of time change. For this reason, the differences arising from time and place are eliminated and consumption is provided at all hours of the day. Since the space is more attractive and spectacular, the capacity to sell goods and services has increased. The material of the building in Alipaşa is stone and brick, these materials do not have reflective surfaces. Different lighting techniques were not used in the bazaar. For this reason, it is less attractive than Margi. Time and space are felt in the bazaar, and the life in the bazaar flows with the urban life. The products exhibited in stacks on the stalls and in front of the shops in Alipaşa destroy the feature of the interior space, which reflects the historical quality of the space, to be spectacular.

Socialization: A self-sufficient urban public space has been created in Margi where all the needs of people are met. Different functions for social, cultural and entertainment purposes are included that will bring the concept of show to the forefront and thus increase the consumption activity. This situation offers consumers the opportunity to socialize. Although shopping is more individual in Margi, functions such as dining, cinema, playgrounds other than shopping provide the opportunity to socialize. In Alipaşa, customers have the opportunity to socialize by entering into verbal dialogue with the sellers. However, there are no other activities other than shopping, so people spend a short time with their relatives.

\begin{abstract}
Ability to engage in activities other than shopping: Margi has different service units that can respond to the daily activities of the customer. These are functions such as shopping in stores, eating in restaurants, chatting in cafes, watching movies in the cinema, and resting in seating units. Spatial arrangements that fulfill functions are structured in a way that contributes to infrastructural relations, aimed at increasing consumption action. On the other hand, in Alipaşa Bazaar, there are no other services other than shopping. Alipaşa has the feature of being a place to be visited rather than a place to spend time. It includes the function of creating shopping and public spaces rather than services.
\end{abstract}

Shopping under all seasonal conditions: Margi has an understanding of gathering under a shell instead of a specific facade. This shell isolates the interior space from the outside and breaks the relationship with it. Although there are openings between different masses, the inward shaping of the stores and mechanical ventilation systems enable the shopping activity to be carried out in all seasonal conditions. Hyperreal environments are created with a sense of spacelessness and timelessness. There are no ventilation systems in Alipaşa. The changes of the seasons and temperature differences are felt in the space.

\title{
7. CONCLUSION AND EVALUATION
}

Capitalist space has produced social practices in which the body is on the back burner through habitus. Therefore, daily life has become standard. In the production of capitalist space, quantitative values have 
been taken into consideration, and the connection with place and geography has been broken. Space is an intermediary in capitalist relations. Daily life has lost its meaning as social, cultural and geographical values are pushed to the background in the production of the space. In metropolises, the production process has been quantified, space and time have gained an abstract character and consumption have developed in parallel with production. Spatial organizations in the metropolis have supported these features of the metropolis and developed system-oriented.

In order to understand the system-oriented development of space and how the space transforms with the society, it is necessary to examine the practices produced by the system and the reasons for the formation of these practices. Because practices are objective properties of space, they can be easily observed and classified. Consumption practices observed in Edirne are specified in the table below according to the spaces examined (Table 2). According to the results obtained from the table, Margi Shopping Center has contributed to the progress of the city center in the direction of Istanbul today as it succeeds in socializing, being accessible, responding to consumption practices, describing the products separately, providing an attractive and spectacular place, defining the space from the outside, making safe shopping, appealing to the customer, engaging in activities other than shopping, shopping in all seasonal conditions, increasing consumption, being able to act freely and move horizontally and vertically. These economy-based practices that take place in the space have also directed human life to consumption. However, Margi contributes to capital flow as consumption is a basic need and is an extension of the production system. This reality makes it difficult for Alipaşa Bazaar to take a place in global economic and urban development. However, according to Margi, Alipaşa has more ability to have an urban function because it contributes to the flow of the city. (Figure 6-7) Alipaşa has the ability to survive in the future on account of this quality. This situation must be realized with the bazaar being included in the global economy. According to the results of the study, the reuse of Alipaşa should not be done in order to shorten the cycle period of the economic system, but to ensure that the consumption, which is a natural need, is realized according to today's conditions. The functioning of Alipaşa in accordance with its historical identity and architectural structure will strengthen its role in the city and the historical urban core will regain its important structure. (Figure 8-9) As a result of this study, it has been revealed that the interventions that need to be made in the recycling process, the new concepts used in consumption spaces should be addressed in a holistic manner with the traditional spatial features existing in Alipaşa.

Table 2. Social practices observed in Edirne

\begin{tabular}{|l|c|c|}
\hline \multicolumn{1}{|c|}{ Social Practices } & Alipaşa Bazaar & Margi Mall \\
\hline Accessibility and parking & - & + \\
\hline Having an urban function & + & + \\
\hline Being able to define the space from outside & - & + \\
\hline Safe shopping & - & + \\
\hline Responding to consumption demands & - & + \\
\hline Being able to appeal to the customer & - & + \\
\hline To be able to freely act of consumption & - & + \\
\hline Ability to increase consumption & - & + \\
\hline To be able to describe the products separately & - & + \\
\hline Ability to move around in the store & - & + \\
\hline Ability to move horizontally and vertically & - & + \\
\hline Providing an attractive and spectacular space & - & + \\
\hline Socialization & + & + \\
\hline Ability to engage in activities other than shopping & - & + \\
\hline Shopping in all seasonal conditions & - & + \\
\hline
\end{tabular}




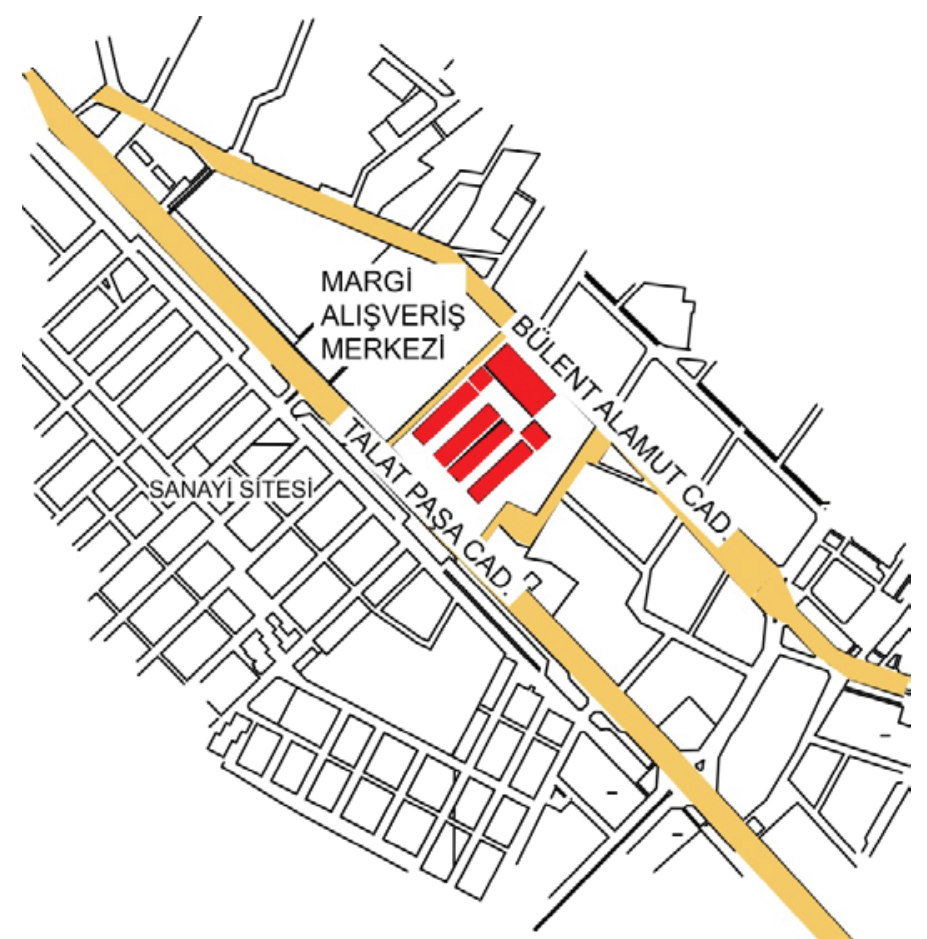

Figure 6. Presentation of the relationship between Margi Shopping Mall and its environment [31]

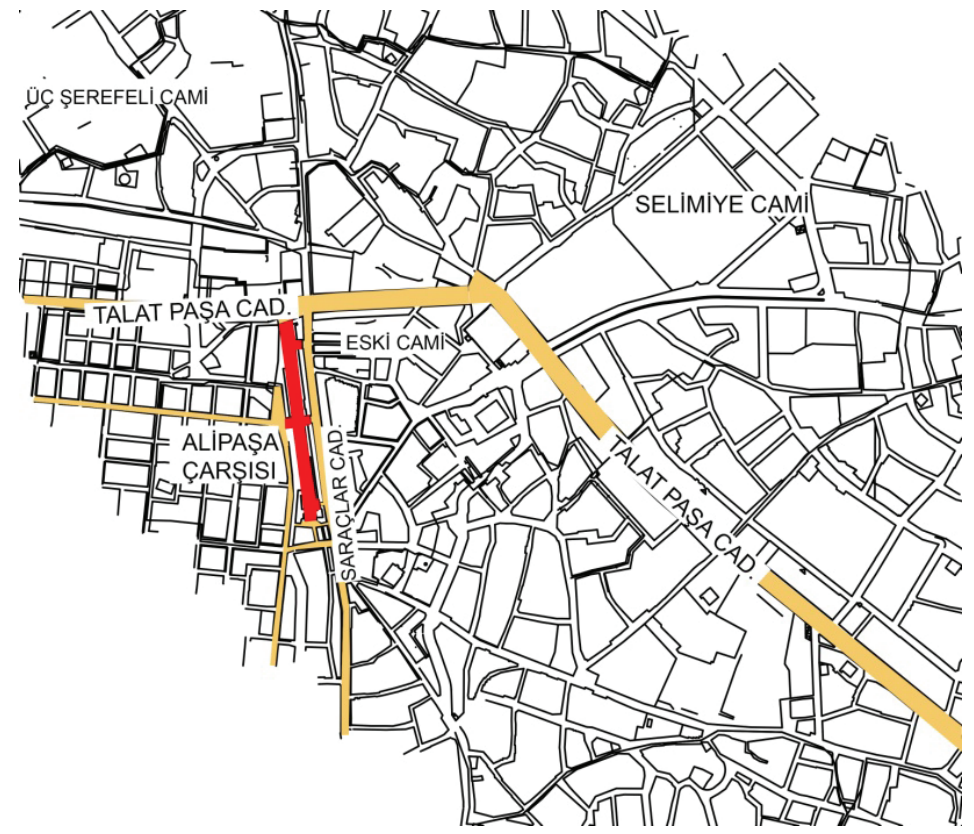

Figure 7. Presentation of the relationship between Alipaşa Bazaar and its environment [31] 


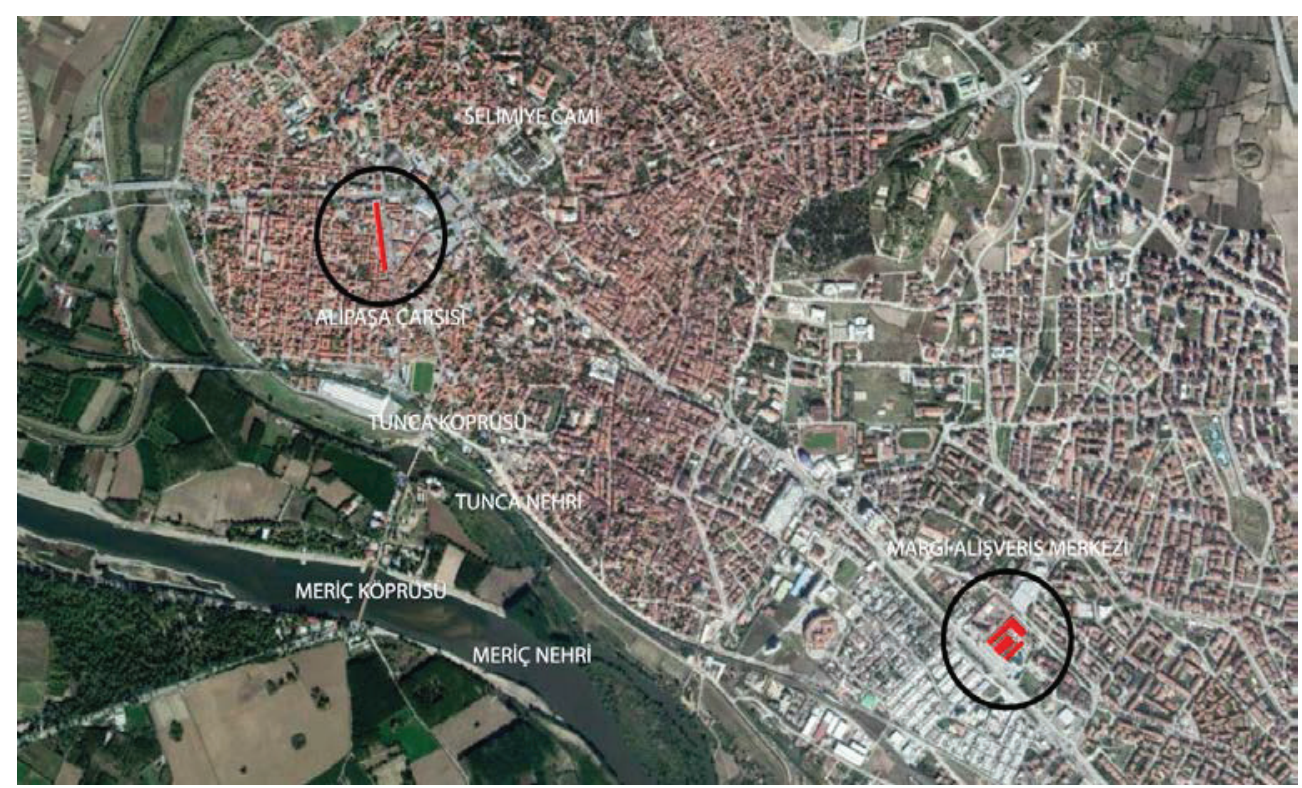

Figure 8. Historical center, Alipaşa Bazaar, and Margi Shopping Mall [26]

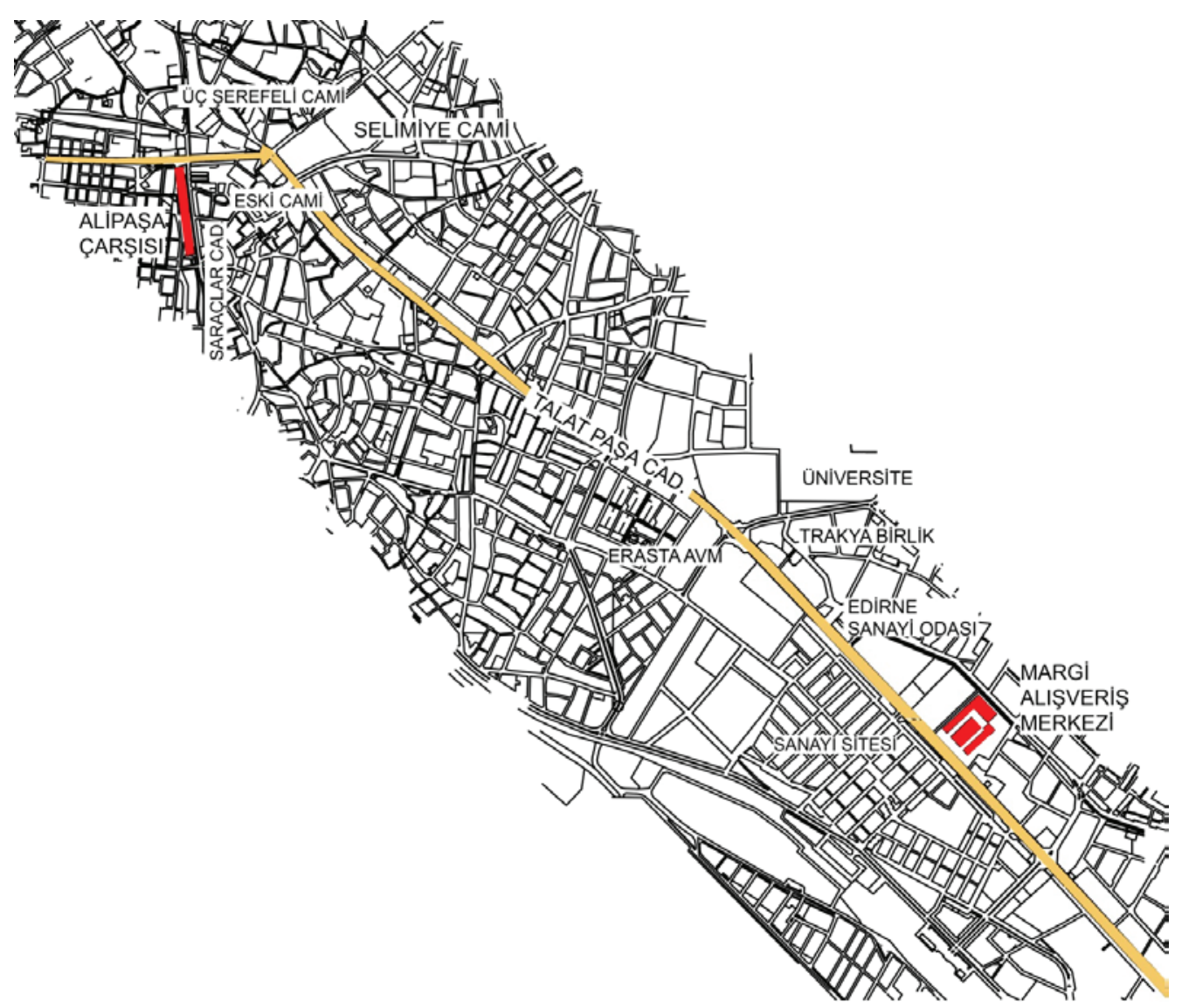

Figure 9. Alipaşa Bazaar and Margi Shopping Mall urban transportation axis [31]

In the study, the practices created by the principles that add circulation value to the consumption spaces were examined and it was reached the view that making the necessary transformations for the implementation of these practices in the spaces outside the process will accelerate the protection of local values. It is not the constant repetition of similar shopping spaces, but the integration of today's facilities 
with local values, the handling of traditional architectural features with new concepts will make cities more livable, strengthen the relationship between space and time, and the qualities of the place will be preserved. In the study, it is also emphasized that the lifestyle that comes with modernization requires more complex spatial organizations. The infrastructural formation of these spatial organizations shows the effect of capitalist capital accumulation on urban development. Comparison of spaces in terms of practices should reveal the relations of people, space and society, specify the relationship of spatial organizations with the city, and enable us to examine the infrastructural formation of the space.

\section{REFERENCES}

[1] Bocock, R., (2014) Tüketim. Dost Kitabevi. Ankara

[2] Harvey, D., (2012). Postmodernliğin Durumu. Metis Yayınc1lı. İstanbul.

[3] Featherstone, M., (2013) Postmodernizm ve Tüketim Kültürü. Ayrıntı Yayınları. İstanbul.

[4] Yırtıcı, H., (2005) Çağdaş Kapitalizmin Mekansal Örgütlenmesi. İstanbul Bilgi Üniversitesi Yayınları. İstanbul

[5] Hasol, D., (2005) Ansiklopedik Mimarlık Sözlüğü. Yapı-Endüstri Merkezi Yayınları. İstanbul

[6] Lefebvre, H., (2014) Mekanın Üretimi. Sel Yayıncılık. İstanbul

[7] Bourdieu, P. Wacquant, L., (2014) Düşünümsel Bir Antropoloji İçin Cevaplar. İletişim Yayınları. İstanbul.

[8] Çeğin, G., Göker, E., Arlı, A., Tatlıcan, Ü. (2014) Ocak ve Zanaat Pierre Bourdieu Derlemesi. İletişim Yayınları. İstanbul

[9] Giddens, A., (2000) Tarihsel Materyalizmin Çağdaş Eleştirisi. Paradigma Yayınları. İstanbul.

[10] Harvey, D., (2015) Marx'ın Kapital'i İçin Klavuz. Metis Yayıncılık. İstanbul

[11] Urry, J. (2015) Mekanları Tüketmek. Ayrıntı Yayınları. İstanbul

[12] Giddens, A., (2014) Modernliğin Sonuçları. Ayrıntı Yayınları. İstanbul

[13] Castells, M. (2014) Kent Sinıf İktidar. Phoenix Yayınevi. Ankara

[14] Morley, D., Robins, K. , (2011) Kimlik Mekanları. Ayrıntı Yayınları. İstanbul

[15] Vural, T., (2005) Değişen Üretim-Tüketim İlişkileri Bağlamında Alışveriş Merkezlerinin Anlamsal ve Mekânsal Dönüşümüne Eleştirel Bir Bakış. İstanbul Teknik Üniversitesi. Fen Bilimleri Enstitüsü. Doktora Tezi. İstanbul

[16] Birol, G. (2005) Çağdaş Alışveriş Merkezlerinde Kent Dokusunun Yeniden Yorumlanması, Gazi Üniversitesi Mühendislik Mimarlık Fakültesi Dergisi, cilt 20, no. 4, Ankara

[17] Cerasi, M. M. (1999) Osmanlı Kenti, Yapı Kredi Yayınları, İstanbul

[18] Gemici, E., (2007) Gündelik Hayatın, Mekân Pratikleri ile İlişkisinde Yeni Kamusal Alanların Yorumlanması Alı̧sveriş Merkezleri. İstanbul Teknik Üniversitesi. Fen Bilimleri Enstitüsü. Yüksek Lisans Tezi. İstanbul

[19] Vural, T. (2009) Türkiyedeki Alışveriş Merkezleri İncelemelerine Eleştirel Bir Bakış: Yorumlar, Eleştiriler, Tartışmalar. Uludağ Üniversitesi Mühendislik Mimarlık Fakültesi Dergisi. cilt 14, no. 1. Bursa

[20] Baudrillard, J. (1998) Simülakrlar ve Simulasyon. Dokuz Eylül Yayınları. İzmir

[21] Gottdiener, M., (2005) Postmodern Göstergeler. İmge Kitabevi. Ankara

[22] Baudrillard, J. (2013) Tüketim Toplumu. Ayrıntı Yayınları. İstanbul

[23] Ritzer, G., (2014) Toplumun McDonaldlaştırılması. Ayrıntı Yayınları. İstanbul

[24] Edirne Ticaret ve Sanayi Odası Rehberi (1985) 100. Yıl Anısına 1885-1995. Arba ve Edirne Türk Kütüphaneciler Derneği. İstanbul

[25] Sönmez, Ö. A., (2011) Geçmişten Günümüze Edirne İli'nin Sosyal Analizi. Trakya Üniversitesi.

Sosyal Bilimler Enstitüsü. Yüksek Lisans Tezi. Edirne

[26] Google Earth Hava Fotoğrafı

[27] Özdeş, G. 1988. Türk Çarşıları. Tepe Yayınları. Ankara

[28] Uysal, B., Fotoğraf

[29] Edirne Mef Mimarlık Margi Alışveriş Merkezi Avan Projesi Çizimleri. Edirne

[30] URL: https://margioutlet.com/.

[31] Uysal, B., Çizim 


\section{BÍLGE UYSAL}

She got her bachelor degree at Department of Architecture at Uludağ University in 2012. She got Erasmus Program at FH-Aachen in Germany in 2011. She got her master degree at Department of Architecture at Trakya University in 2016. She worked as a Research Assistant of Department of Architecture at Trakya University since 2013. She assisted architectural projects courses and basic design cources at Department of Architecture at Trakya University. Her research interests lie in architecture along with urban sociology, behavioral sciences, urban geography and urban planning.

\section{SENNUR AKANSEL, Prof. Dr.}

She graduated from Trakya University, Faculty of Engineering and Architecture, Department of Architecture in 1985 and started to work as a research assistant in the same year. She completed her MSc. in 1991 and her $\mathrm{PhD}$ in 2000 at the Faculty of Architecture at Trakya University. She received the title of doctor lecturer in 2001, associate professor in 2014 and professor in May 2020. She gives lectures on architectural projects, theory of knowledge in architecture, housing design, health and educational buildings at the Faculty of Architecture at Trakya University. In addition, she teaches traditional residential architecture, new building design in the historical environment, publicity in the recreational sphere at the Institute of Science at Trakya University. 